\title{
Lability of proteinaceous material in estuarine seston and subcellular fractions of phytoplankton
}

\author{
A. K. Laursen, L. M. Mayer*, D. W. Townsend \\ Department of Oceanography, University of Maine, Darling Marine Center, Walpole, Maine 04573, USA
}

\begin{abstract}
The rate of proteolysis of amino acids was used to assess the nutritional lability of various materials making up estuarine seston in 3 Maine, USA, estuaries. Physical separations of subcellular fractions of phytoplankton cells led to higher proteolysis rate constants for the cytoplasmic fraction $\left(>1.2 \mathrm{~h}^{-1}\right)$ than for the membrane fraction $\left(0.2\right.$ to $\left.1 \mathrm{~h}^{-1}\right)$. Whole cells, copepod fecal pellets, bottom sediments, and estuarine seston had overlapping ranges of rate constants of 0.17 to $1.3 \mathrm{~h}^{-1}$, which were indistinguishable from one another. Protein pools in the seston of these estuaries throughout the seasons were dominated by phytoplankton production and its fresh detrital products. Inverse relationships between proteolysis rate constants for estuarine seston and the ratios of pheopigments to chlorophyll indicates that the average lability of seston decreases with the disappearance of cytoplasmic material in suspension. This kinetic approach to the quality of food resources implies the existence of different pools of digestible protein for estuarine heterotrophs with different gut residence times. Preferential enrichment of membrane components in sestonic detritus may result from the differential lability of proteins in cytoplasm versus membrane components of cells.
\end{abstract}

KEY WORDS: Estuaries - Seston · Protein · Peptides · Lability $\cdot$ Phytoplankton

\section{INTRODUCTION}

Particulate amino acids form one of the most important pools of nutrition for heterotrophic organisms, due to both their abundance relative to other compound classes and their critical role in biomass formation by the heterotrophs. As a result, this compound class has received considerable attention from persons concerned with nutritional ecology. The lability, or susceptibility to digestion by heterotrophs, of these compounds ranges widely - from easily digestible proteins in biomass to refractory peptides that persist on geological time scales (Cowie \& Hedges 1992). Most work concerned with nutritional quality has focused on standing stocks of available material, with less attention to the kinetic aspects of availability.

Lability is often interpreted from changes in standing stocks, which of course reflects net rather than gross susceptibility to loss. The nutritional ecology of hetero-

-Addressee for correspondence.

E-mail:lmayer@maine.maine.edu trophs, however, could be better understood if more direct measurements of lability were available. Specifically, the digestion kinetics of different pools of particulate amino acids needs attention. The potential role of digestion kinetics in food quality was shown by Reinfelder \& Fisher $(1991,1994)$ in their measurements of assimilation efficiencies in copepods and bivalve larvae feeding on phytoplankton. Quantities of radiolabelled elements assimilated were directly related to their presence in the cytoplasmic content of phytoplankton. Their results indicated that the animals were obtaining nearly all of their nutrition from the soluble cellular material of the cytoplasm. The authors suggested that the short gut residence time in these zooplankton $(<30 \mathrm{~min})$ is insufficient to assimilate the insoluble material associated with the membrane and cell wall. Assimilation efficiencies of animals with rapid digestive strategies indicated that 2 pools of cellular material (both containing significant quantities of protein) were present with different labilities.

Following these observations, we have directly measured the susceptibility to proteolytic attack (i.e. labil- 
ity) of several materials that contribute to estuarine seston, including phytoplankton cells and their cytoplasmic and membranous fractions, zooplankton fecal pellets and estuarine bottom sediments. We have also measured the lability of bulk estuarine seston, along with other environmental variables, to test if variations in the seston's lability might be related to the concentrations of these possible contributors. Our measure of lability assays the rate of hydrolysis of enzymatically hydrolysable amino acids (EHAA) under attack by a standard protease (Mayer et al. 1995).

\section{METHODS}

Field sampling. Estuarine seston samples were collected in the Damariscotta, Sheepscot, and Kennebec River estuaries, located adjacent to one another along the west central coast of Maine, USA. The 3 systems share many characteristics, but differ in their freshwater inflow, receiving ca $10^{0}, 10^{1}$, and $10^{2} \mathrm{~m}^{3} \mathrm{~s}^{-1}$, respectively. Estuarine samples were collected during September 1994, and February, May, June, July, and August 1994, using Niskin bottles. Water samples were prefiltered through 200 or $225 \mu \mathrm{m}$ mesh to remove zooplankton and larger particles determined to be outside the feeding range of a typical filter feeder. The samples were then filtered immediately for analysis of EHAA (2 to $41,47 \mathrm{~mm}$ Whatman $\mathrm{GF} / \mathrm{C})$, phytoplankton pigments (2 I, $47 \mathrm{~mm} \mathrm{GF} / \mathrm{C})$,

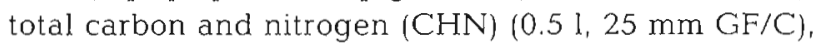
and total suspended particulate material (SPM) (0.5 l, $0.4 \mu \mathrm{m} 47 \mathrm{~mm}$ Poretics PCTE). All filters, with the exception of SPM, were frozen shipboard at $-20^{\circ} \mathrm{C}$ and transferred to $\mathrm{a}-80^{\circ} \mathrm{C}$ freezer within 2 to $6 \mathrm{~h}$ of collection.

EHAA analysis. Filters for the determination of EHAA were analyzed using the enzymatic digestion technique of Mayer et al. (1995), modified for filters. Ten $\mathrm{ml}$ of $0.1 \mathrm{M}$ sodium phosphate buffer ( $\mathrm{pH} 8$, poisoned with pentachlorophenol and sodium arsenate) was added to the filters in plastic scintillation vials and incubated for $1 \mathrm{~h}$ to inhibit bacterial uptake of amino acids. To begin the enzymatic digestion, $1 \mathrm{ml}$ of $1.0 \mathrm{mg}$ $\mathrm{ml}^{-1}$ proteinase $\mathrm{K}$ (Sigma, St. Louis, MO, USA, crude fungal protease) was added to each vial and the samples were incubated on a rotary shaker for $6 \mathrm{~h}$. Subsamples were collected immediately after buffer addition as sample blanks (time, $t=-1 \mathrm{~h}$ ), immediately before and after addition of enzyme $(t=-0 \mathrm{~h}$ and $t=$ $0 \mathrm{~h}$, respectively), and at 1,3 , and $6 \mathrm{~h}$. The sampling before enzyme addition $(t=-0)$ was only necessary for fresh cultures and cell fractionation experiments. The low molecular weight material solubilized from the substrate was separated from the analytical enzymes by trichloroacetic acid precipitation, followed by $6 \mathrm{~N}$ $H C: l$ hydrolysis of the low molecular weight fraction, and analysis of total amino acids as their ortho-phthaldialdehyde (OPA) derivatives with a Hitachi F-4500 spectrofluorometer. Details are provided in Mayer et al. (1995). Relative standard deviations for the 8 analytical replicates from each digested filter were $<10 \%$.

The rate constants for hydrolysis were calculated by fitting the 0 to $6 \mathrm{~h}$ time course data to the exponential equation

$$
C_{t}=C_{\mathrm{A}}-C_{\mathrm{S}} \exp (-k t)
$$

where $C_{t}$ is the EHAA concentration at time $t_{1} C_{A}$ is the asymptotically approached total EHAA concentration, $C_{S}$ is the EHAA concentration of the slowly hydrolyzable pool of peptide substrate, and $k$ is a first-order rate constant describing the slower hydrolysis of the peptide substrate by the analytical enzymes. These time course incubations were performed on a subset of the samples, from 10 stations in the Damariscotta in May and from 3 stations in each of the 3 estuaries in the months June, July, and August 1995. Single-point EHAA concentrations ( $6 \mathrm{~h}$ incubation) were measured on all other samples collected, typically 4 to 6 depths from 6 to 11 stations in each estuary.

Pigment analysis. Phytoplankton pigments were measured in estuarine seston by 2 methods, in order to assess the status of its phytoplanktonic components. All samples collected were analyzed in duplicate for chlorophyll a and pheopigments, using the standard fluorometric technique with acidification step (Parsons et al. 1984). Detailed pigment compositions were determined on the subset of samples used for EHAA kinetics. Pigments were extracted according to the procedure of Bidigare (1991) and analyzed using high performance liquid chromatography (HPLC) following the method of Van Heukelem et al. (1992). Pigments were identified and quantified based on comparisons with standards analyzed by the same procedure. (Available standards were obtained from Sigma. Fucoxanthin and peridinin were graciously provided by $\mathrm{R}$. Bidigare and D. Repeta, respectively.) For those standards not commercially available, such as the chlorophyll degradation products, retention times were determined using the products of controlled degradations of pure culture extracts (Barrett \& Jeffrey 1971) and concentrations calculated using referenced extinction coefficients (Lorenzen \& Downs 1986).

Phytoplankton cell fractionations. Fresh cultures of Tetraselmis suecica, Isochrysis galbana, Rhodomonas sp., and Thalassiosira pseudonana $(3 \mathrm{H})$ were used to examine the lability of EHAA in live algae. Growth conditions were $24 \mathrm{~h}$ of light in $\mathrm{f} / 2$ medium with sterilized seawater for approximately $1 \mathrm{wk}$. All 4 species were separated into cytoplasmic and membranous 
fractions to determine the lability of EHAA from these fractions. Cytoplasmic fractions were analyzed from Tetraselmis suecica and Thalassiosira pseudonana samples only, while membranous fractions were analyzed from all 4 species. In addition, all of the culture species were analyzed as whole unfractionated cells.

Phytoplankton cultures were fractionated following the basic procedure of Hellebust \& Craigie (1978). Pure cultures (50 to $150 \mathrm{ml}$, depending on culture density) were separated from the culture medium by centrifugation (5 min, $8000 \times g$, Sorvall RC-5B), and resuspended in 15 to $25 \mathrm{ml}$ artificial seawater (30 psu). Microscopy revealed no evident cell damage. Cells were lysed by sonicating over ice for a total of $1.5 \mathrm{~min}$ in $15 \mathrm{~s}$ bursts (Fisher 300, 35\%, $4 \mathrm{~mm}$ tip). Samples were then immediately centrifuged at high speed $\left(60 \mathrm{~min}, 48000 \times g, 0\right.$ to $5^{\circ} \mathrm{C}$ ) to separate into cytoplasmic (supernatant) and membranous (pellet) fractions. These fractions were frozen $\left(-20^{\circ} \mathrm{C}\right)$ and analyzed for the kinetics of EHAA digestion, as described above, within 1 to $2 \mathrm{~d}$.

Other analyses and experiments. Total particulate carbon and nitrogen concentrations were measured on a Perkin Elmer 2400 Series II CHNO/S Elemental Analyzer Total SPM was evaluated according to Strickland \& Parsons (1972).

To establish the lability of a component representing digested material from zooplankton consumption, copepod fecal pellets were collected from the bottom of a culture flask of Calanus finmarchicus (fed on a diet of mixed flagellates), examined to remove any copepods, centrifuged to remove the culture medium, and frozen at $-20^{\circ} \mathrm{C}$. The pellets were then resuspended in poisoned phosphate buffer, and analyzed for EHAA. following primarily the procedure described above for filters. The only modification was a brief centrifugation of the sample before subsampling to prevent loss of pellet mass. Following the $6 \mathrm{~h}$ digestion process and a final centrifugation, the remaining buffer was decanted and the pellets were freeze-dried. EHAA content was normalized to the final dry weight of the analyzed pellets.

EHAA from bottom sediment samples were previously analyzed by L. Schick according to the procedure of Mayer et al. (1995). Only frozen sediment samples were used for this study, to remain consistent with sample pretreatment of the seston.

\section{RESULTS}

The lability of several possible components of seston, including algal cells, fecal pellets, and bottom sediment, was analyzed by comparing their hydrolysis rate constants. Our assay measures hydrolytic produc- tion of low molecular weight (MW) peptides and monomeric amino acids that are absorbable by metazoan systems (Matthews 1991). Time courses of digestion of most material showed no low MW material until the analytical enzymes were added. However, the cytoplasm separates of phytoplankton cells often did contain some pre-existing low MW amino acids. This low MW material is certainly relevant as food, but in order to establish comparative rate constants for lability of high MW material, it was necessary to subtract the low MW fraction (value at $t=-0$ ) and bring the hydrolysis curves through zero at $t=-0$ (plotted as $-0.1 \mathrm{~h}$ ). The hydrolysis rate constant then becomes a measure of the hydrolytic lability of the high MW material and is comparable among all types of samples analyzed regardless of the quantity of low MW material present.

Cultured Tetraselmis suecica and Thalassiosira pseudonana samples, which were separated into cytoplasmic and membranous fractions, show strong evidence of different labilities of EHAA within different fractions of cells. Pairwise comparisons of membrane and cytoplasmic lability always showed cytoplasmic proteins to hydrolyze more quickly (Fig. 1). Cytoplasmic EHAA rate constants showed considerable variability but were all greater than $1.2 \mathrm{~h}^{-1}$ (Fig. 2). Membranous EHAA was more difficult to hydrolyze, with rate constants ranging from 0.22 to $0.99 \mathrm{~h}^{-1}$. There was no significant difference between the lability of the same fractions from different algal species.

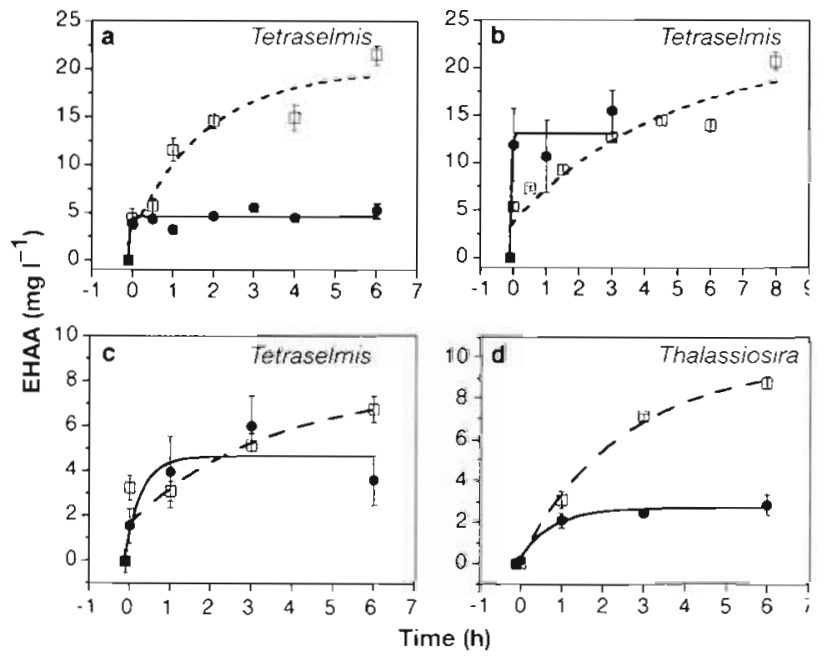

Fig. 1. Time courses of EHAA evolution from phytoplankton cell separations of 3 replicate cultures of Tetraselmis suecica and one of Thalassiosira pseudonana. (-) Cytoplasm; ( $\square$ ) membrane separates. First-order proteolysis rate constants $\left(\mathrm{h}^{-1}\right)$ are (a) cytoplasm: 18.4 , membrane: 0.56 ; (b) cytoplasm: 23.9, membrane: 0.22 ; (c) cytoplasm: 2.49, membrane: 0.3; (d) cytoplasm: 1.3, membrane: 0.4 


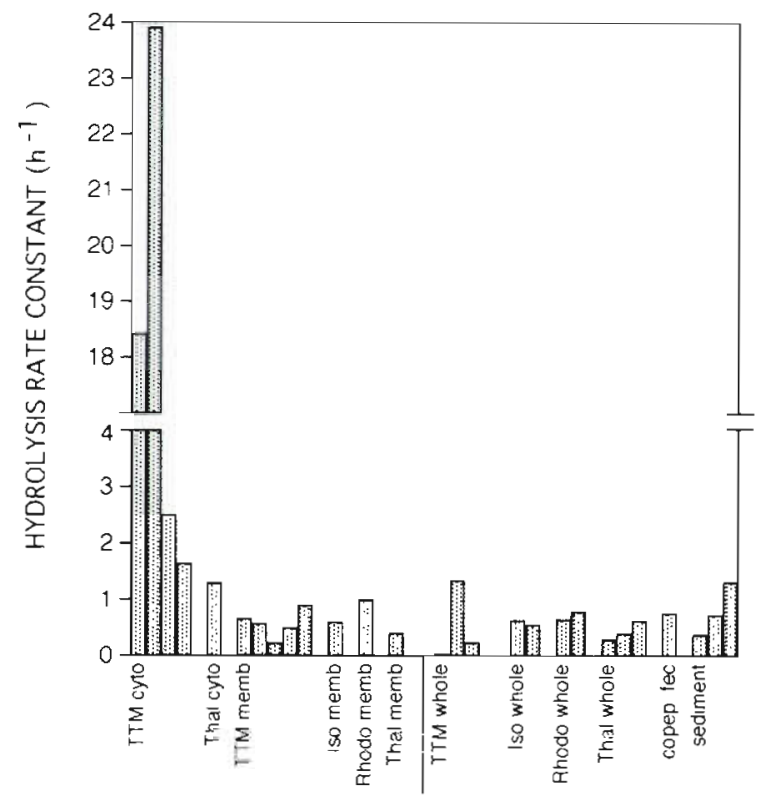

Fig. 2. Proteolysis rate constants $\left(\mathrm{h}^{-1}\right)$ for all cell separates, whole cells, fecal pellets, and bottom sediment. Replicates are grouped. TTM: Tetraselmis suecica: Thal: Thalassiosira pseudonana; Iso: Isochrysis galbana; Rhodo: Rhodomonas sp.; memb: membrane; cyto: cytoplasm; copep fec: fecal pellets from Calanus finmarchicus fed on mixed flagellate diet; sedi-

ment: bottom sediment from the Damariscotta estuary

The cytoplasm fractions accounted for 20 to $60 \%$ (mean $=46 \%, \mathrm{n}=14$ ) of the total EHAA recovered and the membrane fractions accounted for the remaining 40 to $80 \%($ mean $=54 \%, n=14)$. These percentages can vary depending on the growth phase of the phytoplankton cells, with more protein in the membrane during the exponential growth phase (Reinfelder \& Fisher 1991). Thus, with a significant fraction of the EHAA in the membrane fraction, coupled to considerable variability in rate constants, we found no significant difference between whole cell and membrane fractions with this small number of samples.

The rate constant for EHAA hydrolysis in the copepod fecal pellet was $0.75 \mathrm{~h}^{-1}$, similar to those of the membrane fractions and whole cells. Rate constants for 3 , freeze-dried, bottom sediment samples were also similar, at $0.37,0.72$ and $1.3 \mathrm{~h}^{-1}$ (Fig. 2).

Samples of estuarine seston showed excellent fits to the first-order rate law (Fig. 3). Hydrolysis rate constants of field samples from the Damariscotta, Sheepscot, and Kennebec estuaries ranged from 0.17 to $1.1 \mathrm{~h}^{-1}$. Surface and bottom water samples were collected and analyzed with the hypothesis that some difference in the nature of EHAA would be seen between surface phytoplankton and resuspended bottom sediments, but differences were not significant.

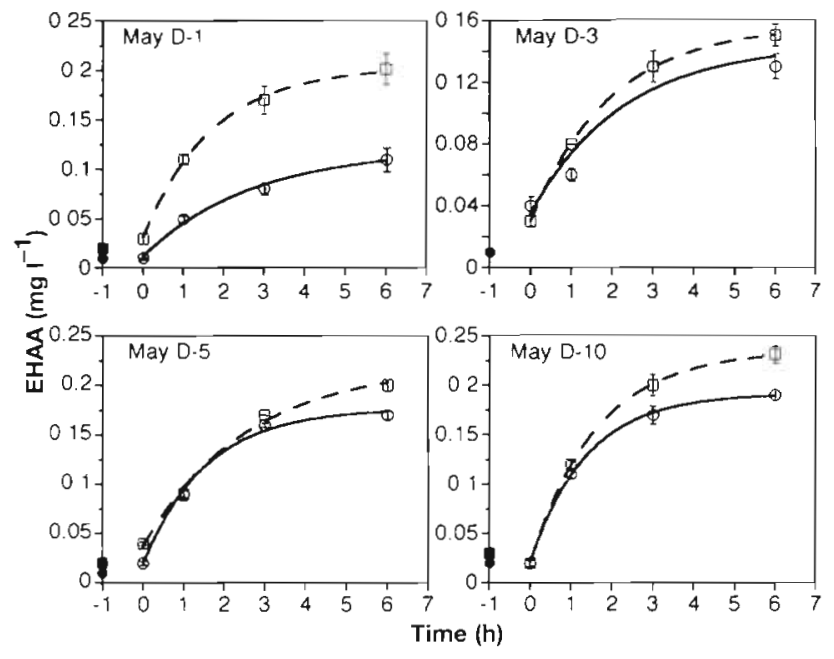

Fig. 3. Representative time courses for EHAA release from several field samples, as mg EHAA l $^{-1}$ estuarine water, from the Damariscotta estuary. Stations D-1 to D-10 progress from the mouth to the head of the estuary. $(O, \bullet)$ Surface; $(\square, \square)$ bottom samples. Solid symbols are $t=-1 \mathrm{~h}$ samples, collected before addition of enzyme, and are not included in the firstorder curve fits

Concentrations of EHAA in the 3 estuaries ranged from 0.04 to $0.87 \mathrm{mg} \mathrm{l}^{-1}$ during May through August, with highest values in the Damariscotta estuary during June, closely followed by those in the Kennebec also during June. These high values corresponded with a secondary spring phytoplankton bloom during June in all 3 estuaries with chlorophyll $a$ values peaking between 4.0 and $8.7 \mu \mathrm{g}^{-1}$. Concentrations of EHAA in the Sheepscot were about half those of the other 2 systems, a ratio which remained consistent throughout much of the summer. Over the summer, chlorophyll a concentra-

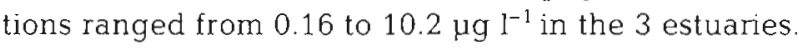
Chlorophyll degradation products were usually present in lower concentrations. Chlorophyll a concentrations followed patterns similar to the EHAA concentrations, both temporally and spatially. Fucoxanthin was the primary carotenoid found, consistent with a dominance of diatoms in cell counts (M. Wong pers. comm.).

The contribution of live algal cells to particulate organic nitrogen (PON) was estimated assuming a C:chlorophyll ratio of 50 and a C:N ratio of 7 for phytoplankton. In the 3 estuaries, phytoplankton contributed 31 to $93 \%$ of the total PON, with maxima during June. Because of the variability of the C:chlorophyll ratio from the literature, this calculation merely shows that phytoplankton biomass made up a significant to major fraction of the PON Similarly, the contribution of EHAA-nitrogen to the total PON was calculated assuming an EHAA:N ratio of 6, due to the fact that the amino acid composition of EHAA is similar to that of average biological proteins (Mayer et al. 1995). 
Fig. 4. Scatter plots of EHAA and particulate organic nitrogen (PON) vs chlorophyll and suspended particulate matter (SPM), for all data taken in the 3 estuaries over the year. While all correlations are significant, EHAA and PON correlate more strongly with chlorophyll than with SPM
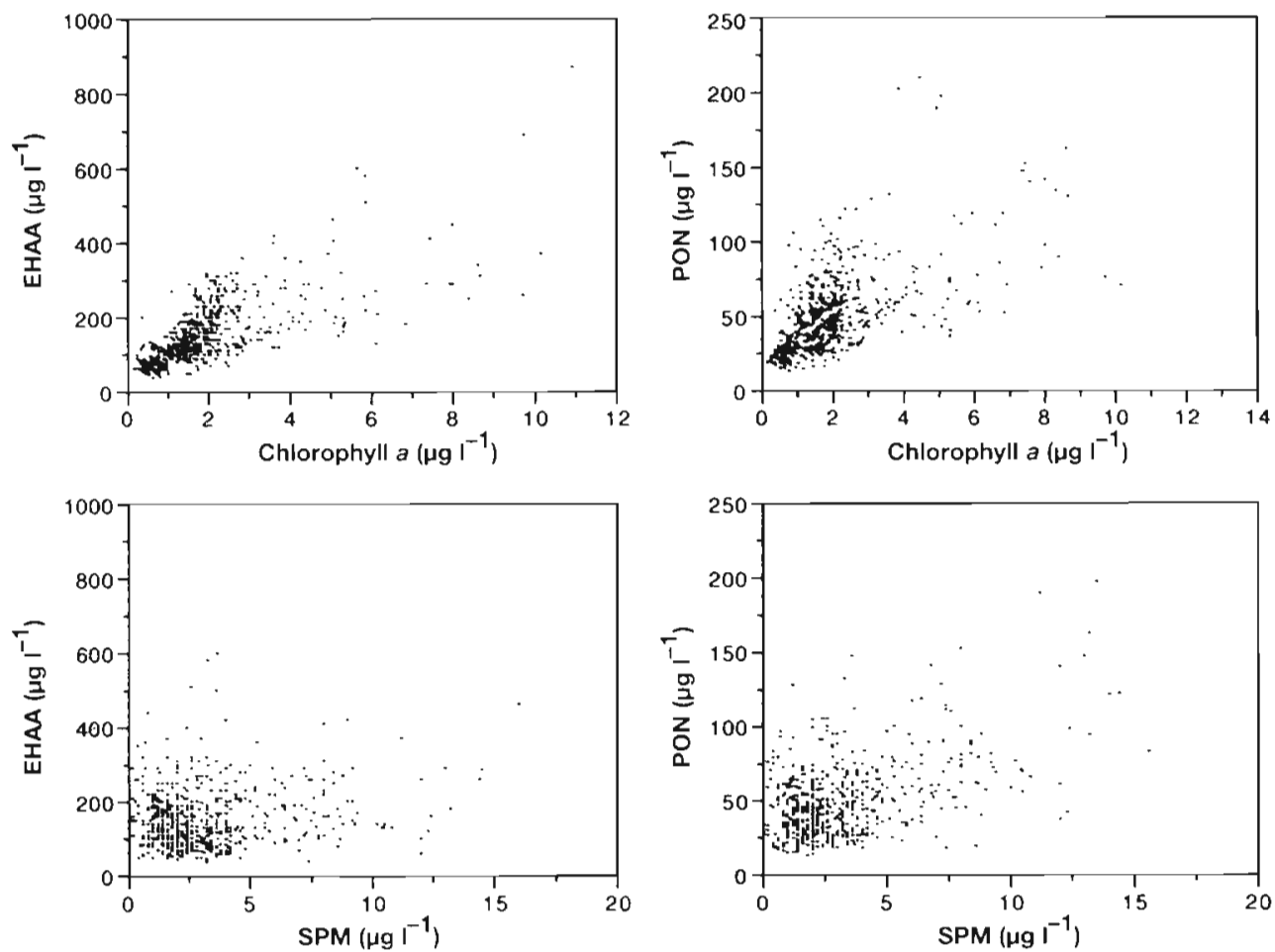

EHAA thus made up 37 to $63 \%$ of the PON, which is a much higher proportion than has been found for nitrogen in bottom sediments (Mayer et al. 1995). Stronger correlations of both the EHAA and total PON with chlorophyll a than with total SPM (Fig. 4) reinforce the inference that the nitrogenous materials derive primar- ily from recent algal production rather than sediment introduction to the water column.

Is the sestonic EHAA in the form of living or detrital algal material? Frequency histograms of the EHAA:chlorophyll a ratio of the estuarine samples (Fig. 5) provide some indication. Diatoms, which dom-
Fig. 5. Ratios of sestonic EHAA to chlorophyll for each estuary from September 1993 to August 1994, plotted as frequency histograms. Maximum $x$-axis value for frequency has been normalized to the same length for all plots to increase legibility. Length of bars is thus relative fraction of total samples. The typical live phytoplankton value encountered in the literature is 40 , and is indicated by a dashed line. Values above 100 likely indicate the presence of detrital EHAA in excess of that provided by live phytoplankton cells
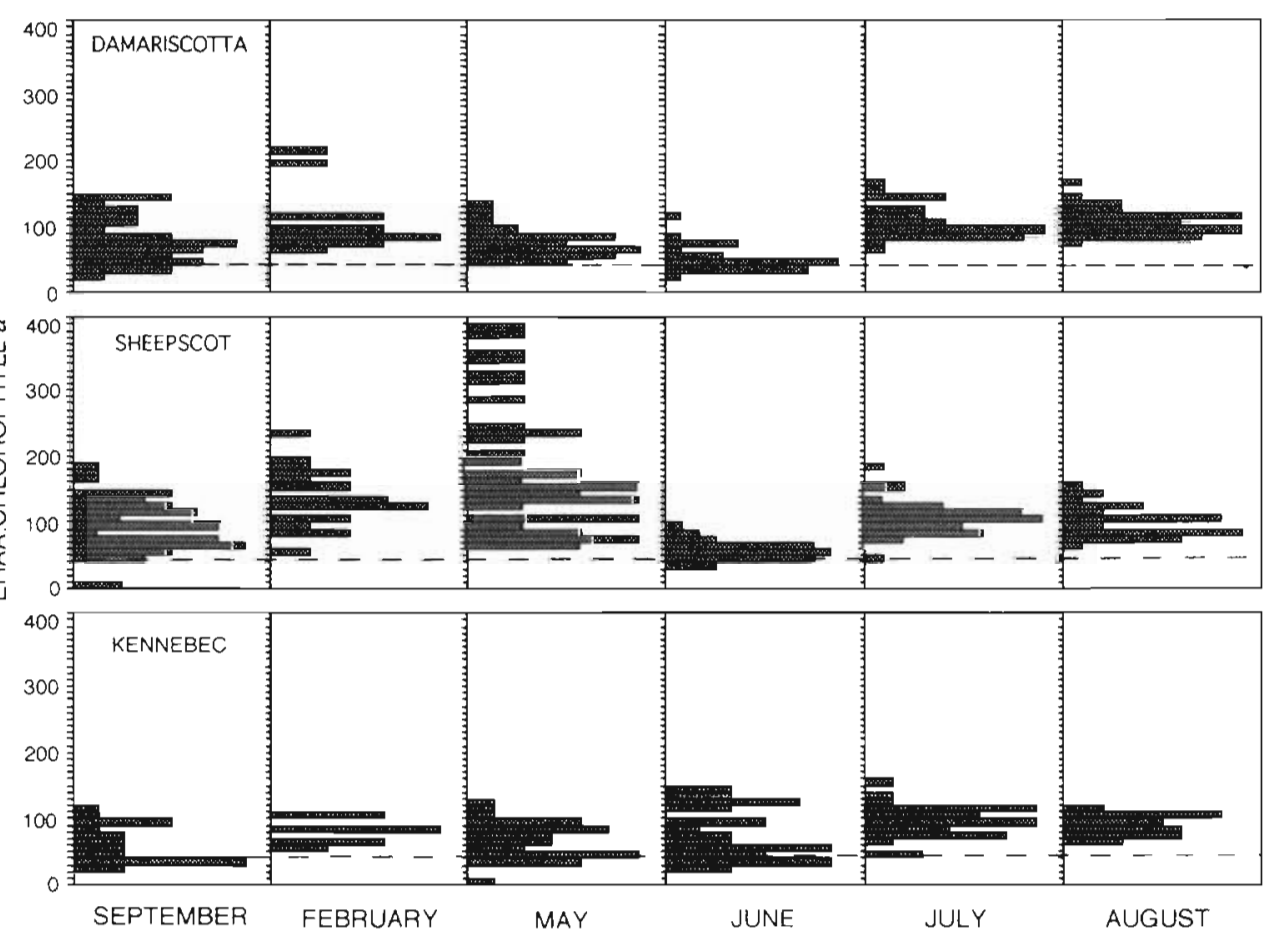
inated the flora in these estuaries, typically have protein:chlorophyll a ratios of 20 to 100 on a wt/wt basis, though values up to 172 have been reported (Moal et al. 1987, Dortch \& Packard 1989) Values $>100$ were commonly found at most times of the year in our study, which probably indicates the presence of detrital EHAA in addition to the EHAA provided by live cells. The June samples, with a strong mode at a ratio of 40 , corresponded to the secondary spring bloom with high chlorophyll a concentrations. Samples from other months were typically dominated by higher values, with an occasional mode also at ca 40 (e.g. May Kennebec samples). The summer values following the June bloom (July, August) were particularly high, corresponding with maximum levels of algal pigment decay products (authors' unpubl. data). Overall, the EHAA:chlorophyll a ratio and its close proximity to typical phytoplankton culture ratios suggests that the EHAA was contamed in either living cells or fairly fresh detritus derived from recent algal production. However, the uncertainty in the ratio for living cells precludes accurate quantitation of the relative amounts of live and detrital algal material.

Concentrations of SPM reflected the different volumes of freshwater inflow. SPM in the Damariscotta ranged from 0.1 to $8.0 \mathrm{mg} \mathrm{l}^{-1}$. The Sheepscot, with an order of magnitude greater freshwater input, had slightly higher SPM concentrations ranging from 0.4 to $12.3 \mathrm{mg} \mathrm{l}^{-1}$ SPM in the Kennebec, which has still another order of magnitude greater inflow, was the most concentrated of the three, ranging from 0.5 to 44 mg $1^{-1}$. Values increased towards the heads of all 3 estuaries. Particulate organic matter (POM, calculated as $2 \times$ particulate organic carbon) generally made up 20 to $50 \%$ of the SPM.

\section{DISCUSSION}

The algal fractionation experiments showed that EHAA from cytoplasmic material is much more labile than that from cell membranes. The slowness of digestion of the membrane proteins is due to their partial embedding in the lipid bilayer. The embedded portions of membrane proteins are protected against access by proteolytic enzymes (Walker \& Fearnley 1986), until they can be separated from the lipid by lipolytic or detergent action. We found occasional rapid hydrolysis of a small fraction of membrane proteins, which likely represents their exposed peptide constituents. Lability of algal proteins is therefore dependent on their location in the cell. Growth phase may affect lability of whole phytoplankton cells, as cell protein is more concentrated in the membrane during the exponential growth phase and more concentrated in the cytoplasm during the stationary phase (Reinfelder \& Fisher 1991).

Analysis of the kinetics of EHAA digestion in fresh algal cultures (fractionated and whole cells), copepod fecal pellets, and sediments demonstrate a range in peptide lability. Different labilities of possible seston components indicated that fast and slow pools of EHAA do exist, and evidence for these pools can be sought in field situations. The correlations between the nitrogenous components of seston and chlorophyll, as well as the organic-rich nature of the seston (Fig. 4), indicate that the seston from these estuaries offer an opportunity to seek variations in EHAA lability that correspond to the transition from fresh phytoplankton cells to their detrital products.

The conversion of algal biomass to detritus might be expected to change the EHAA lability in seston from a relatively high value due to the presence of cytoplasmic material to lower values that reflect loss of the cytoplasmic component. Evidence for this change is observed in this data set through the inverse correlation between hydrolysis rate constants and chlorophyll a degradation products (Fig. 6). The inverse relationship is highly significant $(p<0.001)$, showing that the conversion of algal biomass to detritus, likely resulting from grazing activity, lowers the average lability of the remaining peptide material

We had originally expected more pronounced changes in the hydrolytic rate constant with different samples. It is possible that variations were dampened somewhat by freezing of the filters before analysis; logistic considerations prevented doing this study with unfrozen seston. Mayer et al. (1995) showed that freezing increases both the amount and rate constant of amino acids released upon proteolytic attack on sediment. Sun et al. (1993) showed that freezing increases the susceptibility of chlorophyll, another compound contained within lipid bilayers, to decay in sediments

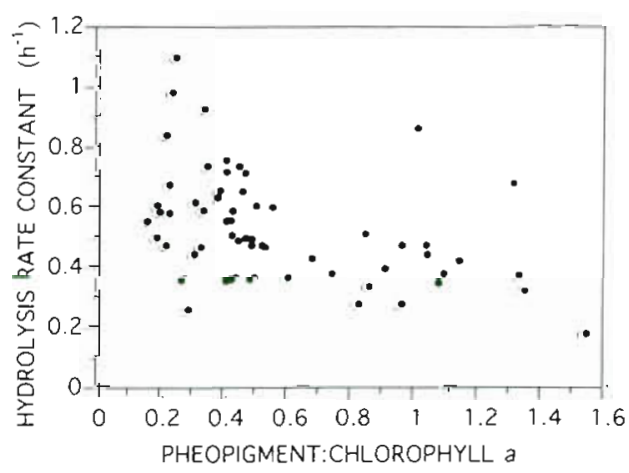

Fig. 6. Proteolysis rate constants for estuarine seston vs the pheopigment:chlorophyll a ratio $(p<0.001)$ for the months June, July, and August. Pigments by the Parsons et al. method 
Freezing may thus partially expose membrane proteins to proteolytic attack and obscure differences among samples.

Nevertheless, the overall correlations in Fig. 6 illustrate that the presence of intact phytoplankton cells provides a source of quickly digestible substrate for consumers. A low rate constant does not necessarily indicate lack of such quickly digestible substrate, because these rate constants represent averages of heterogeneous particle assemblages present in the seston. Averaging of EHAA lability across the many particles on a filter may not present an appropriate picture of the food available to an individual animal. Quickly digestible substrate is available to zooplankton through selective feeding (Poulet 1983, Cowles et al. 1988), even when its presence is not strongly indicated in the overall lability of particulates collected on a bulk-sampling filter.

These results suggest that detritus may be selectively enriched in membrane fragments of cells with associated proteins that have survived gut passage. Many zooplankton are capable of digesting components of membranes; for example, polyunsaturated fatty acids can be removed during gut passage (Prahl et al. 1984). Nevertheless, some membrane components, e.g. sterols, can transit the gut with relatively little loss. Sterols can rigidify regions of lipid bilayer membrane, so that this transit may represent gut passage of relatively indigestible membrane fragments, perhaps with associated proteins. Such a scenario would imply appearance of membrane fragments in the fine particle and colloidal size range, as in the prediction of Jumars et al. (1989) that inefficient digestion should lead to excretion of 'dissolved' materials. Evidence for this pathway includes the appearance of plant pigments in the colloidal size fraction (Bianchi et al. 1995), direct expulsion of lipid-associated proteins after protozoan digestion (Nagata \& Kirchman 1992), and the budgetary loss of pigment from particulate fractions during copepod digestion (Roy et al. 1989). Bacterial membrane materials, which do not contain sterols, may also selectively survive gut passage; evidence is the recent discovery of bacterial porin proteins in the 'dissolved' fraction of seawater (Tanoue et al. 1995).

This suggestion that membrane proteins may be a source of slowly decomposable proteins in seston does not exclude other possibilities. For example, Mayer et al. (1995) suggested that bacterial S-layer proteins make up the slowly hydrolyzable fraction of EHAA in sediments.

The kinetics of EHAA digestion shown in this study does not necessarily equal the kinetics in animal guts. Hydrolysis rates under the protease conditions of this assay have been shown to equal those of the digestive fluids of a sea cucumber for unfrozen sediment (Mayer et al. 1995), but their relation to the digestive kinetics of other animals is not known. The hydrolytic rate constants presented here, therefore, provide an ordinal rather than an absolute estimation of lability. Nevertheless, the results of this study are consistent with the relative gut residence times of animals in marine settings. Zooplankton, such as copepods and bivalve larvae, have gut residence times of $10 \mathrm{~min}$ to $1 \mathrm{~h}$, and some may specialize in consuming algal cytoplasm (Reinfelder \& Fisher 1991, 1994). On the other hand, benthic deposit- and suspension-feeders, such as bivalves and polychaetes, have gut residence times of 1 to $12 \mathrm{~h}$ and may be more capable of digesting membranous components. Intracellular digestive capability may be especially important in allowing digestion of membrane materials (McHenery \& Birkbeck 1985).

Acknowledgements. We thank the crew of the RV 'Gulf Challenger' for their fine support. Assistance in the lab and field was provided by Y. Hagiwara, L. Schick, J. Brown, K. Hardy, M. Thiel, B. Hu, G. Teegarden, and Z. Chen. P. Blades-Ecklebarger graciously provided the phytoplankton cultures. This work was supported by NOAA Sea Grant and NSF Biological Oceanography. Contribution \#293, Darling Marine Center

\section{LITERATURE CITED}

Barrett J, Jeffrey SW (1971) A note on the occurrence of chlorophyllase in marine algae. J Exp Mar Biol Ecol 7: $255-262$

Bianchi TS, Lambert C. Santschi PH, Baskaran M, Guo L (1995) Plant pigments as biomarkers of high-molecular weight dissolved organic carbon. Lumnol Oceanogr 40: $422-428$

Bidigare RR (1991) Analysis of algal chlorophylls and carotenoids. In: Hurd DC, Spencer D (eds) Marine particles: analysis and characterization. Geophys Monogr 63, Amer Geophys Union, Washington, DC, p 119-128

Cowie GL, Hedges JI (1992) Sources and reactivities of amino acids in a coastal marine environment. Limnol Oceanogr $37: 703-724$

Cowles TJ, Olson RJ, Chisholm SW (1988) Food selection by copepods: discrimination on the basis of food quality. Mar Biol 100:41-49

Dortch Q, Packard TT (1989) Differences in biomass structure between oligotrophic and eutrophic marine ecosystems. Deep Sea Res 36:223-240

Hellebust JA, Craigie JS (1978) Handbook of phycological methods: physiological and biochemical methods. Cambridge University Press, Cambridge

Jumars PA, Penry DL, Baross JA, Perry MJ, Frost BW (1989) Closing the microbial loop: dissolved carbon pathway to heterotrophic bacteria from incomplete ingestion, digestion, and absorption in animals. Deep Sea Res 36:483-495

Lorenzen CJ, Downs JN (1986) The specific absorption coefficients of chlorophyllide $a$ and pheophorbide $a$ in $90 \%$ acetone, and comments on the fluorometric determination of chlorophyll and pheopigments, Limnol Oceanogr 31. $4.49-452$

Matthews DM (1991) Protein absorption: development and present state of the subject. Wiley-Liss, New York 
Mayer LM, Schick LL, Sawyer T, Plante CJ, Jumars PA, Self RL (1995) Bioavailable amino acids in sediments: a biomimetic, kinetics-based approach. Limnol Oceanogr 40:511-520

McHenery JG, Birkbeck TH (1985) Uptake and processing of cultured microorganisms by bivalves. J Exp Mar Biol Ecol 90:145-163

Moal J, Martin-Jezequel V, Harris RP, Samain JF, Poulet SA (1987) Interspecific and intraspecific variability of the chemical composition of marine phytoplankton. Oceanol Acta 10.339-346

Nagata T, Kirchman DL (1992) Release of macrornolecular organic complexes by heterotrophic marine flagellates. Mar Ecol Prog Ser 83:233-240

Parsons TR, Maita Y, Lalli CM (1984) A manual of chemical and biological methods for seawater analysis. Pergamon Press, Oxford

Poulet SA (1983) Factors controlling utilization of non-algal diets by particle-grazing copepods. A review. Oceanol Acta 6:221-234

Prahl FG, Eglinton G, Corner EDS, O'Hara SCM, Forsberg TEV (1984) Changes in plant lipids during passage through the gut of Calanus. J Mar Biol Ass UK 64:317-334

Reinfelder JR, Fisher NS (1991) The assimilation of elements ingested by marine copepods. Science 251:794-796

This article was submitted to the editor
Reinfelder JR, Fisher NS (1994). The assimilation of elements ingested by marine planktonic bivalve larvae. Limnol Oceanogr 39:12-20

Roy S, Harris RP, Poulet SA (1989) Inefficient feeding by Calanus helgolandicus and Temora longicornis on Coscinodiscus wailesii: quantitative estimation using chlorophyll-type pigments and effects on dissolved free amino acids. Mar Ecol Prog Ser 52:145-153

Strickland JDH, Parsons TR (1972) A practical handbook of seawater analysis, 2nd edn. Bull Fish Res Bd Can 167

Sun MY, Lee C, Aller RC (1993) Laboratory studies of oxic and anoxic degradation of chlorophyll-a in Long Island Sound sediments. Geochim Coscmochim Acta 57:147-157

Tanoue E, Nishiyama S, Kamo M, Tsugita A. (1995) Bacterial membranes: possible source of a major dissolved protein in seawater. Geochim Cosmochim Acta 59:2643-2648

Van Heukelem L, Lewitus AJ, Kana TM (1992) High-performance liquid chromatography of phytoplankton pigments using a polymeric reversed-phase $C_{18}$ column. J Phycol 28 $867-872$

Walker JE, Fearnley IM (1986) Sequence analysis of membrane proteins. In: Ragan CI, Cherry RJ (eds) Techniques for the analysis of membrane proteins. Chapman and Hall London, p 243

Manuscript first received: July 31, 1995

Revised version accepted: December 12, 1995 